\title{
Thermal Performance Analysis of Exterior Wall Materials of Huizhou Residential Buildings Adapted to Local Climate
}

\author{
Bin Zheng*, Jieli Sui, Yanhui Tan, Lingling Zhang \\ Yantai University Architecture School, Yantai 264005, China
}

Corresponding Author Email: archiwolf@163.com

https://doi.org/10.18280/acsm.430204

Received: 20 January 2019

Accepted: 9 March 2019

\section{Keywords:}

climatic environment, adaptability,

Huizhou residential buildings, structure of

exterior wall material, thermal

performance

\begin{abstract}
The exterior wall, essential to the envelope structure of Huizhou residential buildings, enjoys a unique ability to adapt to the local environment and climate. However, there is a lack of experiments and quantitative data on the thermal performance of exterior wall materials, owing to the complexity in the current situation of Huizhou residential buildings. Therefore, the purpose of this study is to explore the physical properties and energy transfer features of the exterior walls of Huizhou residential buildings. Specifically, the thermal performances of four types of walls of Huizhou residential buildings, with different materials and structures, were compared through field survey, field test and lab test. The principal conclusion is that the heat transfer coefficients of the four types of walls, namely, the traditional rowlock cavity wall made from black bricks and yellow mud, the new rowlock cavity wall with cement bricks, the new composite wall of Hongcun Village, and the solid wall of self-built houses in Jicun Village, were respectively, $1.892 \mathrm{~W} / \mathrm{m}^{2} \bullet \mathrm{K}, 2.821 \mathrm{~W} / \mathrm{m}^{2} \bullet \mathrm{K}, 2.024 \mathrm{~W} / \mathrm{m}^{2} \bullet \mathrm{K}$ and 3.588 $\mathrm{W} / \mathrm{m}^{2} \cdot \mathrm{K}$; the traditional rowlock cavity wall made from black bricks and yellow mud boasted the best thermal performance. The research findings lay the basis for the development of ecofriendly walls that adapt to the local climatic environment.
\end{abstract}

\section{INTRODUCTION}

The Huizhou traditional residential buildings in the south of Anhui Province occupy an important position in the history of Chinese residences due to their unique history, culture and geographical location etc. As a representative of traditional Chinese residence, Huizhou residential buildings have attracted the attention of experts and scholars since ancient times. Some of them have mainly studied their unique economic and cultural characteristics, and others focus more on the ecological significance [1-4]. With the development of modern society, Huizhou people have built a variety of new colourful and featured residential forms. As the sustainable development strategies such as rural revitalization and beautiful villages are proposed, architects in the construction of new villages in Huizhou have been paying more attention to the issue of ecological energy conservation in residential buildings while focusing on their historical and cultural factors.

At present, there have been fruitful research on the cultural characteristics of Huizhou residential buildings. Zhao, Shide et al. studied the influence of cultural environment on the inheritance of the Huizhou three carvings (stone, wood and brick carvings) [5]. Regarding the ecological energy conservation in Huizhou residential buildings, Zhijia Huang analysed the causes of natural ventilation in Huizhou residential buildings in summer, and indoor humidity environment [6-7]. Lin Borong et al. explored the importance of sun-shading and heat preservation among the four typical factors forming the summer thermal environment in Huizhou residential buildings, and discussed the evaluation criteria under natural ventilation [8]. Li, Shang-Lin et al. studied an automatic modelling method based on constructive grammar for building Chinese Huizhou traditional vernacular houses, embodying the eco-type of construction [9]. The results of literature search show that the current research on climate adaptability in Huizhou residential buildings has been focused on indoor environment and temperature and humidity testing, but lacking a quantitative analysis on the climate adaptability and thermal performance of walls [10-12], which requires more experimental research and experimental data on the envelop structure such as walls etc. At the same time, there are mature experience in the research of the wall thermal performance which is worth learning [13-16].

In view of this above, the paper analyses the physical properties and structural forms of building materials in Huizhou residential buildings in detail, and tested the thermal performance of four commonly used types of walls. Then, based on the test data, it compares the different thermal performance of the walls adaptable to the climatic environment of Huizhou residential buildings, and analyses the influence of wall materials and construction methods on the thermal performance of the wall. This shall lay a basis for the application of new types of wall in the renewal and protection of Huizhou residential building.

\section{BUILDING MATERIALS AND THEIR PHYSICAL PROPERTIES}

In the Huizhou residential buildings, blocks are mostly used as wall materials. Through field survey, the four most commonly used types of blocks (cement bricks, clay bricks, cement hollow bricks, concrete solid bricks) were selected and tested in terms of their physical properties, namely, bulk 
density, water absorption rate, thermal conductivity, etc. The raw materials and processing techniques of these four blocks were described as follows:

\subsection{Cement brick}

It's a new-type wall material manufactured by pressure moulding using the fly ash, coal slag, coal gangue, tailings slag, chemical slag or natural sand (one or several of these raw materials) as main raw materials, and cement as a coagulant.

\subsection{Clay brick}

Clay brick is made of clay (incl. shale, coal gangue etc.). It's processed by mud, moulded, dried and calcined [17]. As one of the oldest building materials in the world, the clay bricks used in the Huizhou traditional residential buildings are commonly known as black bricks, because the adobe is cooled by water during the firing process, making the $\mathrm{Fe}_{3} \mathrm{O}_{4}$ in the clay appear black in the incomplete oxidation state.

\subsection{Cement hollow brick}

Cement hollow bricks are formed by moulding, demoulding and curing in a special mould. It's different from cement bricks only in moulding and demoulding, but there is no significant difference between them in terms of microstructure of the hardened cement slurry and the coarse aggregate.

\subsection{Concrete solid brick}

Concrete solid bricks consist of cements (cementitious materials), sand and stone (aggregates). After mixing them with water in a certain ratio, it is formed by stirring, moulding, and curing. The coarse aggregate (stone) of this brick has a rather large particle size, so the pores are relatively large, and mostly enclosed.

Table 1. Comparison of the external dimensions among the four types of bricks

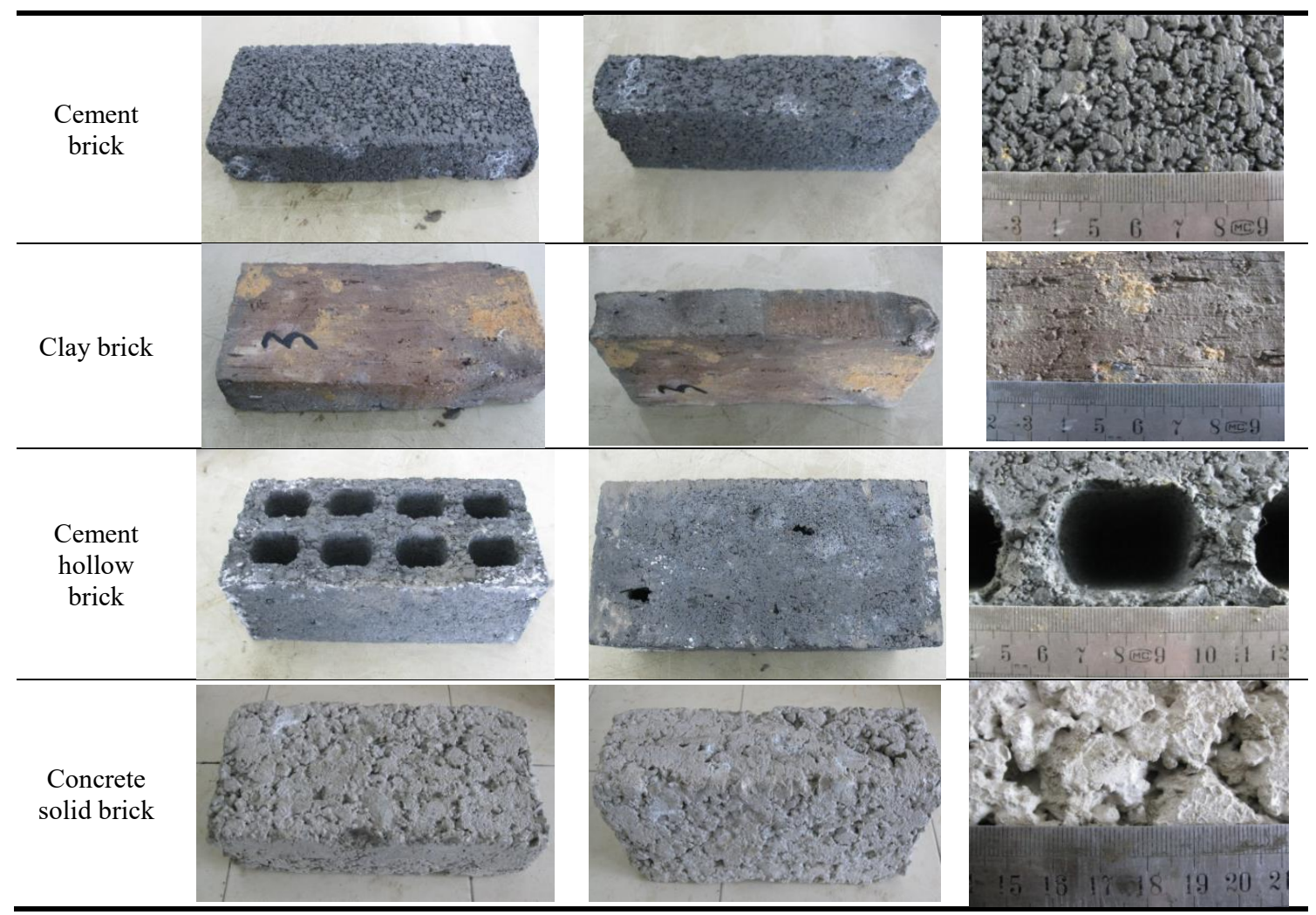

\subsection{Experimental results}

Due to different physical properties of the materials and the different processing techniques, the physical properties of different bricks are significantly different. The physical parameters such as bulk density, water absorption rate and thermal conductivity of the material were tested in the laboratory. The specific values are as follows:

Table 2. Physical property test of common bricks for buildings

\begin{tabular}{cccccccc}
\hline Type & $\begin{array}{c}\text { Length } \\
(\mathrm{mm})\end{array}$ & $\begin{array}{c}\text { Width } \\
(\mathrm{mm})\end{array}$ & $\begin{array}{c}\text { Height } \\
(\mathrm{mm})\end{array}$ & $\begin{array}{c}\text { Weight } \\
(\mathrm{mm})\end{array}$ & $\begin{array}{c}\text { Density } \\
\left(\mathrm{kg} / \mathrm{m}^{3}\right)\end{array}$ & $\begin{array}{c}\text { Water } \\
\text { absorption }\end{array}$ & $\begin{array}{c}\text { Thermal conductivity W/ } \\
(\mathrm{m} \cdot \mathrm{K})\end{array}$ \\
\hline $\begin{array}{c}\text { Cement brick } \\
\text { Clay brick }\end{array}$ & 241 & 110.5 & 50 & 2.657 & 2000 & $5 \%$ & 0.51 \\
$\begin{array}{c}\text { Cement hollow } \\
\text { brick }\end{array}$ & 230 & 112 & 40 & 1.752 & 1730 & $9.7 \%$ & 0.42 \\
$\begin{array}{c}\text { Concrete solid } \\
\text { brick }\end{array}$ & $350 / 40$ & $115 / 30$ & $92 / 80$ & 4.093 & 2013 & $5.3 \%$ & - \\
\hline
\end{tabular}




\section{WALL CONSTRUCTION PRACTICES}

The wall of Huizhou residential buildings mainly adopts the way of block masonry. According to the field survey, four typical types of walls in Huizhou residential buildings were selected as test objects. Their materials and construction methods were introduced in this section.

\subsection{Traditional rowlock cavity wall made from black bricks and yellow mud}

The traditional rowlock cavity wall made from black bricks and yellow mud (Type I) is a commonly used construction method in Huizhou traditional residential buildings. To be specific, the clay bricks are laid on ends to form a cavity and then filled with yellow mud slurry; in order to strengthen the integrity of the wall, the stretcher bonds are made up and down, and one end of the header bond is clamped by two stretchers on one side of the rowlock wall, while the other end is at the midpoint of the stretcher on the other side of the rowlock wall [13] (Figure 1).

\subsection{New rowlock cavity wall with cement bricks}

Cement bricks are used more in the newly built Huizhou residential buildings. The wall tested in the field is build using the new rowlock cavity wall with cement bricks (Type II): the cement bricks are laid on ends, and bonded up and down; one header bond is clamped between the two stretchers, and the header bonds pass through the wall, leaving a cavity in the middle of the stretcher bond (Figure 2).

\subsection{New composite wall with cement hollow brick}

A comprehensive real estate project using the new composite wall with cement hollow brick (Type III) was selected as the test object. Specific practices include: $240 \mathrm{~mm}$ cement porous brick from the inside to the outside, interface mortar, $40 \mathrm{~mm}$ thick rubber powder polystyrene slurry for external insulation, anti-crack mortar composite alkaliresistant fibreglass mesh, elastic prime coats, flexible putty, and high-grade exterior wall paint (Figure 3).

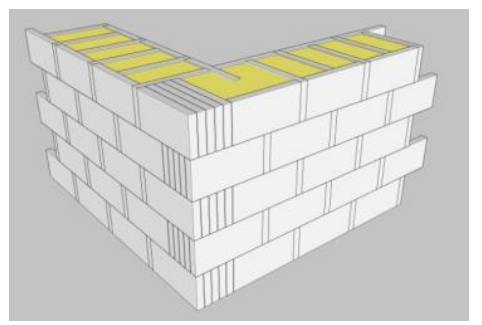

Figure 1. Traditional rowlock cavity wall made from black bricks and yellow mud

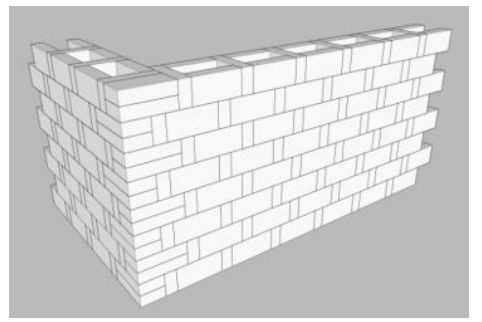

Figure 2. New rowlock cavity wall with cement bricks

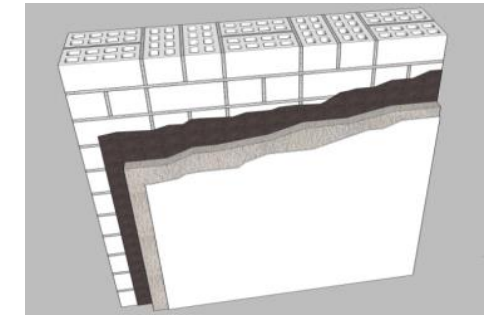

Figure 3. New composite wall with cement hollow brick

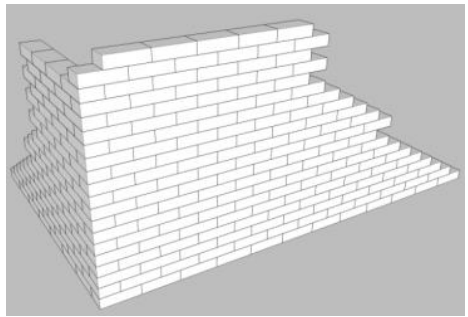

Figure 4. Block building method of self-built house in Ji Village

\subsection{Solid wall of self-built houses in Jicun Village}

The fourth type of wall tested was a self-built house by the farmer using solid concrete bricks (Type IV). Specifically, the block and cross bond was adopted in actual practice (Figure 4).

\section{THERMAL TEST}

\subsection{Test formula}

The thermal resistance value $\mathrm{R}$ is calculated as [19]:

$$
R=\frac{\sum_{j=1}^{n}\left(\theta_{\mathrm{I} j}-\theta_{\mathrm{E} j}\right)}{\sum_{j=1}^{n} q_{j}}
$$

where:

$\mathrm{R}$ - thermal resistance of the envelop enclosure $\left(\mathrm{m}^{2} \cdot \mathrm{K} / \mathrm{W}\right)$;

$\theta_{\mathrm{I} j}$-the jth measurement of internal surface temperature of the envelop enclosure $\left({ }^{\circ} \mathrm{C}\right)$;

$\theta_{\mathrm{E} j}$-the jth measurement of external surface temperature of the envelop enclosure $\left({ }^{\circ} \mathrm{C}\right)$;

$q_{j}$-the jth measured value of heat flux density $\left(\mathrm{W} / \mathrm{m}^{2}\right)$.

The calculation formula used for the heat transfer coefficient $\mathrm{K}$ is:

$$
K=1 /\left(R_{\mathrm{i}}+R+R_{\mathrm{e}}\right)
$$

where:

$K$-heat transfer coefficient of the envelope structure $\left(\mathrm{W} / \mathrm{m}^{2} \cdot \mathrm{K}\right)$;

$R_{\mathrm{i}}$-internal surface heat transfer resistance in accordance with the provisions of Table 2.2 in Appendix 2 of national standard Thermal Design Code for Civil Building (GB501762016);

$R_{\mathrm{e}}$-external surface heat transfer resistance in accordance with the provisions of Table 2.3 in Appendix II of national standard Thermal Design Code for Civil Building (GB501762016). 


\subsection{Test conditions}

The test was performed according to the Energy Efficiency Test Standard for Residential Buildings (JGJ/T132-2009) [20] using the heat flow meter method [21-22]. The Agilent 34970A data acquisition instrument was used to collect data. Considering that it's a heavy-type envelop structure, the test lasted for 96 hours after the test system is stabilized. Data analysis uses the arithmetic mean method. During the test, the outdoor air temperature was between $-4.7^{\circ} \mathrm{C}$ and $14.5^{\circ} \mathrm{C}$, which was a typical winter climate. Three surface temperature test points were set inside and outside the middle of the tested wall, and the average was taken to reduce the error. Two heat sinks were placed in the middle. In order to increase the temperature difference between the internal and external surface temperatures, the inner side was heated by a hot box, and the temperature was set to $35^{\circ} \mathrm{C}$. The sampling interval was 1 hour [23].

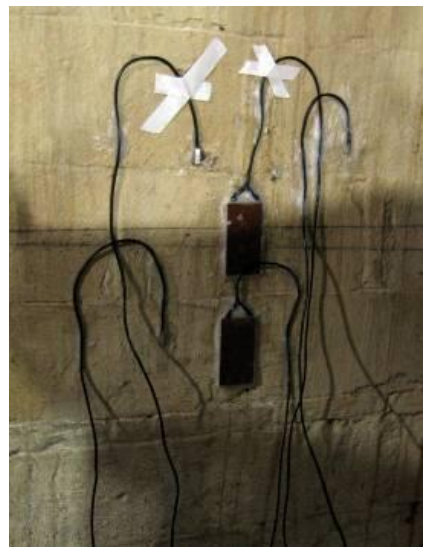

Figure 5. Layout of survey points

\subsection{Test analysis}

Figure 6 shows that in the test of Type I, the internal surface temperature of the wall is between $25.7^{\circ} \mathrm{C}$ and $27.9^{\circ} \mathrm{C}$, which is relatively stable; and the external surface temperature of the wall is between $2.3{ }^{\circ} \mathrm{C}$ and $13.0{ }^{\circ} \mathrm{C}$ changing with the air temperature; mainly affected by the weather changes the heat flow fluctuates between $39.0 \mathrm{~W} / \mathrm{m}^{2}-63.5 \mathrm{~W} / \mathrm{m}^{2}$. It's calculated that the average thermal resistance $R$ of this traditional wall is $0.379 \mathrm{~m}^{2} \cdot \mathrm{K} / \mathrm{W}$, and the average heat transfer coefficient $\mathrm{K}$ of the wall is $1.892 \mathrm{~W} / \mathrm{m}^{2} \bullet \mathrm{K}$.

Figure 7 shows that in the test of Type II, the internal surface temperature of the wall is between $23.1^{\circ} \mathrm{C}$ and $26.1^{\circ} \mathrm{C}$, which is relatively stable; and the external surface temperature of the wall was between $4.2{ }^{\circ} \mathrm{C}$ and $13.3^{\circ} \mathrm{C}$ changing with the air temperature; mainly affected by the weather changes, the heat flow fluctuates between $63.1 \mathrm{~W} / \mathrm{m}^{2}-91.0 \mathrm{~W} / \mathrm{m}^{2}$. It's calculated that the average thermal resistance $\mathrm{R}$ of this wall is 0.205 $\mathrm{m}^{2} \cdot \mathrm{K} / \mathrm{W}$, and the average heat transfer coefficient $\mathrm{K}$ of the wall is $2.821 \mathrm{~W} / \mathrm{m}^{2} \cdot \mathrm{K}$.

Figure 8 shows that in the test of Type III, the internal surface temperature of the wall is between $27.5^{\circ} \mathrm{C}$ and $28.4{ }^{\circ} \mathrm{C}$, which is relatively stable; while the external surface temperature of the wall was between $8.4{ }^{\circ} \mathrm{C}$ and $19.4{ }^{\circ} \mathrm{C}$, changing with the air temperature; heat flow varies more obviously, between $38.5 \mathrm{~W} / \mathrm{m}^{2}$ and $59.0 \mathrm{~W} / \mathrm{m}^{2}$, mainly affected by the weather. It's calculated that the average thermal resistance $\mathrm{R}$ of this wall is $0.345 \mathrm{~m}^{2} \cdot \mathrm{K} / \mathrm{W}$, and the average heat transfer coefficient $\mathrm{K}$ is $2.024 \mathrm{~W} / \mathrm{m}^{2} \bullet \mathrm{K}$.

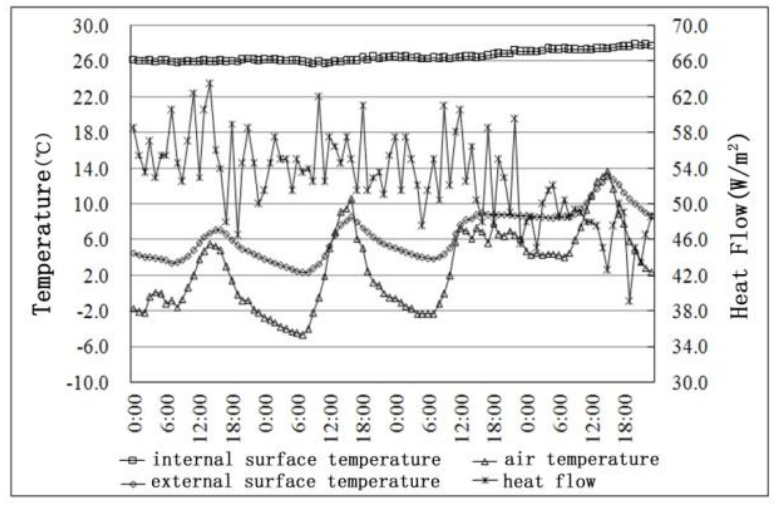

Figure 6. Time-varying curve of traditional rowlock cavity wall made from black bricks and yellow mud

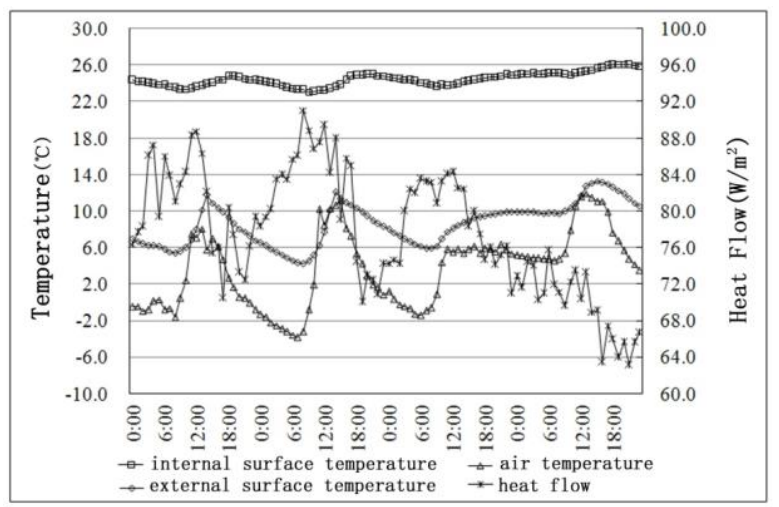

Figure 7. Time-varying curve of new rowlock cavity wall with cement bricks

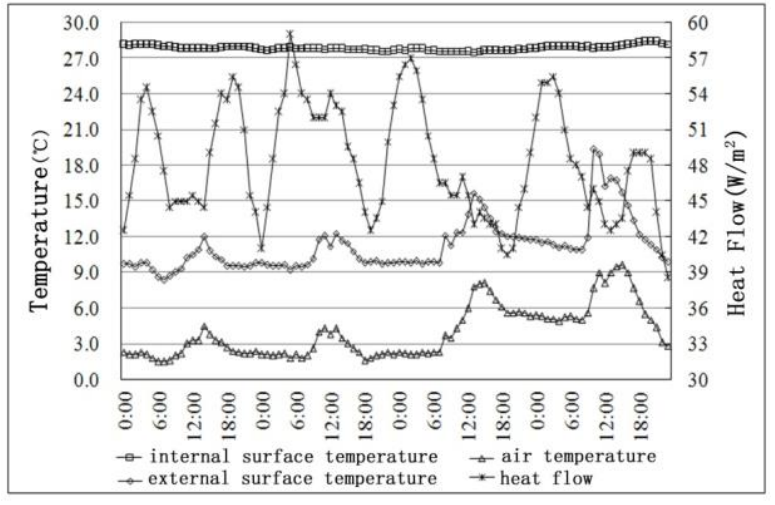

Figure 8. Time-varying curve of new composite wall of Hongcun Village

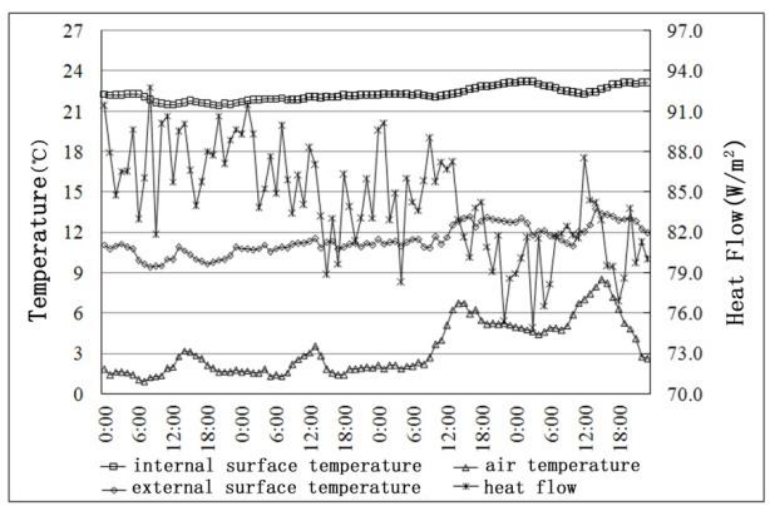

Figure 9. Time-varying curve of the solid wall of self-built houses in Jicun Village 
Figure 9 shows that in the test of Type IV, the internal surface temperature of the wall was between $21.4{ }^{\circ} \mathrm{C}$ and $23.2{ }^{\circ} \mathrm{C}$, which is relatively stable and the external surface temperature was between $9.4{ }^{\circ} \mathrm{C}$ and $13.7^{\circ} \mathrm{C}$, varying with the air temperature; the heat flow varies more obviously, mainly affected by the weather, between $74.9 \mathrm{~W} / \mathrm{m}^{2}-92.8 \mathrm{~W} / \mathrm{m}^{2}$. It's calculated that the average thermal resistance $\mathrm{R}$ of this wall is $0.129 \mathrm{~m}^{2} \cdot \mathrm{K} / \mathrm{W}$, and the average heat transfer coefficient $\mathrm{K}$ is $3.588 \mathrm{~W} / \mathrm{m}^{2} \cdot \mathrm{K}$.

Table 3. Thermal performance test results from January 13 to 16

\begin{tabular}{|c|c|c|c|c|c|c|c|c|}
\hline & \multicolumn{4}{|c|}{$\begin{array}{c}\text { Traditional rowlock cavity wall made from black bricks and } \\
\text { yellow mud }\end{array}$} & \multicolumn{4}{|c|}{ New composite wall with cement hollow brick } \\
\hline & January 13 & January 14 & January 15 & January 16 & $\begin{array}{c}\text { January } \\
13\end{array}$ & $\begin{array}{c}\text { January } \\
14\end{array}$ & $\begin{array}{c}\text { January } \\
15\end{array}$ & $\begin{array}{c}\text { January } \\
16\end{array}$ \\
\hline $\begin{array}{l}\text { internal surface } \\
\text { temperature }\left({ }^{\circ} \mathrm{C}\right)\end{array}$ & 26.06 & 26.13 & 26.57 & 27.47 & 24.06 & 24.02 & 24.34 & 25.44 \\
\hline $\begin{array}{l}\text { external surface } \\
\text { temperature }\left({ }^{\circ} \mathrm{C}\right)\end{array}$ & 4.85 & 4.91 & 6.61 & 9.88 & 7.60 & 7.64 & 8.13 & 11.10 \\
\hline heat flow $\left(\mathrm{W} / \mathrm{m}^{2}\right)$ & 55.58 & 55.01 & 53.08 & 47.43 & 80.48 & 81.56 & 79.03 & 69.42 \\
\hline$R\left(\mathrm{~m}^{2} \cdot \mathrm{K} / \mathrm{W}\right)$ & 0.382 & 0.386 & 0.376 & 0.371 & 0.205 & 0.201 & 0.205 & 0.207 \\
\hline$K\left(\mathrm{~W} / \mathrm{m}^{2} \cdot \mathrm{K}\right)$ & 1.881 & 1.867 & 1.901 & 1.920 & 2.817 & 2.849 & 2.817 & 2.801 \\
\hline
\end{tabular}

Table 4. Thermal performance test results from January 22 to 25

\begin{tabular}{|c|c|c|c|c|c|c|c|c|}
\hline & \multicolumn{4}{|c|}{ New composite wall with cement hollow brick } & \multicolumn{4}{|c|}{ Solid wall of self-built houses in Jicun Village } \\
\hline & $\begin{array}{c}\text { January } \\
22\end{array}$ & $\begin{array}{c}\text { January } \\
23\end{array}$ & $\begin{array}{c}\text { January } \\
24\end{array}$ & $\begin{array}{c}\text { January } \\
25\end{array}$ & $\begin{array}{c}\text { January } \\
22\end{array}$ & $\begin{array}{c}\text { January } \\
23\end{array}$ & $\begin{array}{c}\text { January } \\
24\end{array}$ & $\begin{array}{c}\text { January } \\
25\end{array}$ \\
\hline internal surface temperature $\left({ }^{\circ} \mathrm{C}\right)$ & 27.97 & 27.76 & 27.68 & 28.07 & 21.81 & 21.99 & 22.46 & 22.84 \\
\hline external surface temperature $\left({ }^{\circ} \mathrm{C}\right)$ & 9.75 & 10.27 & 11.82 & 12.98 & 10.25 & 11.02 & 12.00 & 12.41 \\
\hline heat flow $\left(\mathrm{W} / \mathrm{m}^{2}\right)$ & 48.67 & 50.06 & 47.19 & 47.48 & 87.71 & 85.20 & 83.76 & 80.80 \\
\hline$R\left(\mathrm{~m}^{2} \cdot \mathrm{K} / \mathrm{W}\right)$ & 0.376 & 0.348 & 0.336 & 0.320 & 0.132 & 0.129 & 0.125 & 0.129 \\
\hline$K\left(\mathrm{~W} / \mathrm{m}^{2} \cdot \mathrm{K}\right)$ & 1.903 & 2.009 & 2.057 & 2.128 & 3.546 & 3.584 & 3.636 & 3.584 \\
\hline
\end{tabular}

Table 5. Comparison of test results among four types of walls

\begin{tabular}{|c|c|c|c|c|}
\hline & $\begin{array}{l}\text { Traditional rowlock cavity wall made } \\
\text { from black bricks and yellow mud }\end{array}$ & $\begin{array}{l}\text { New composite wall with } \\
\text { cement hollow brick }\end{array}$ & $\begin{array}{l}\text { New composite wall with } \\
\text { cement hollow brick }\end{array}$ & $\begin{array}{l}\text { Solid wall of self-built } \\
\text { houses in Jicun Village }\end{array}$ \\
\hline$R\left(\mathrm{~m}^{2} \cdot \mathrm{K} / \mathrm{W}\right)$ & 0.379 & 0.205 & 0.345 & 0.129 \\
\hline$K\left(\mathrm{~W} / \mathrm{m}^{2} \bullet \mathrm{K}\right)$ & 1.892 & 2.821 & 2.024 & 3.588 \\
\hline
\end{tabular}

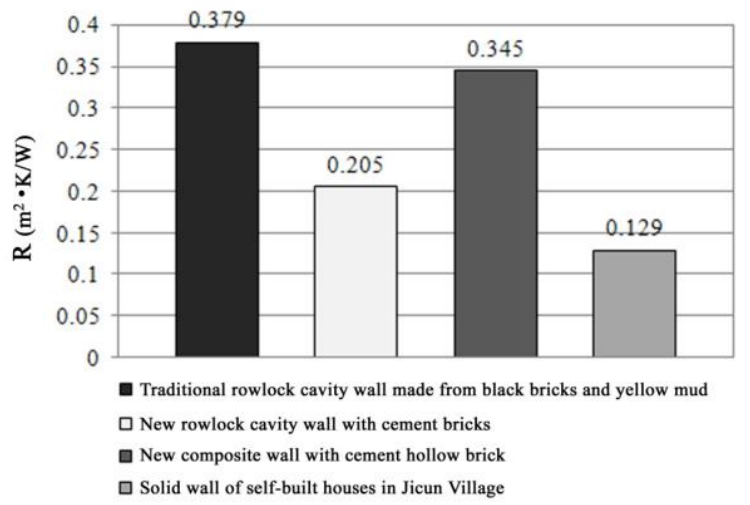

Figure 10. Comparison of average heat resistance among four of walls

\section{CONCLUSIONS}

According to the Energy Efficiency Test Standard for Residential Buildings (JGJ/T132-2009), this paper performed tests on the thermal performance of the materials and construction for the four types of walls adaptable to the local climate environment in Huizhou residential buildings. The conclusions have been drawn as follows:

(1) The thermal conductivity coefficient of the clay brick material is $0.42 \mathrm{~W} /(\mathrm{m} \bullet \mathrm{K})$, the average thermal resistance $\mathrm{R}$ of

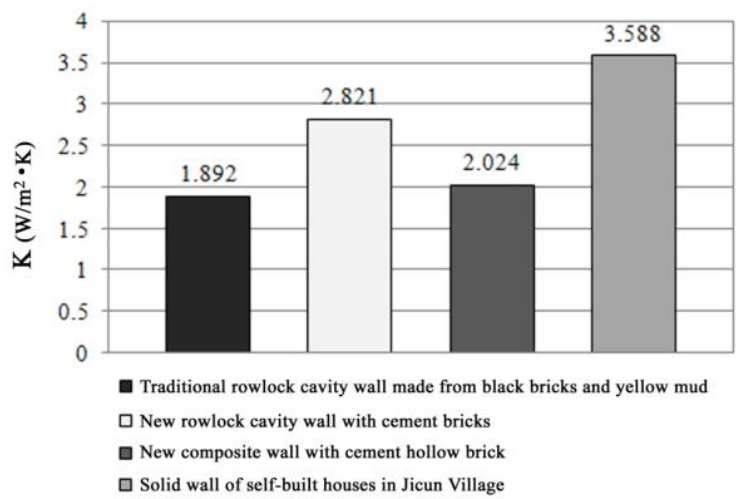

Figure 11. Comparison of average heat transfer coefficient types values among four types of walls

Type I is $0.379 \mathrm{~m}^{2} \cdot \mathrm{K} / \mathrm{W}$, and the average heat transfer coefficient $\mathrm{K}$ of this type of wall is $1.892 \mathrm{~W} / \mathrm{m}^{2} \cdot \mathrm{K}$;

(2) The thermal conductivity coefficient of the cement brick material is $0.51 \mathrm{~W} /(\mathrm{m} \cdot \mathrm{K})$, the average thermal resistance $\mathrm{R}$ of Type II is $0.205 \mathrm{~m}^{2} \cdot \mathrm{K} / \mathrm{W}$, and the wall average heat transfer coefficient $\mathrm{K}$ is $2.821 \mathrm{~W} / \mathrm{m}^{2} \cdot \mathrm{K}$;

(3) For Type III, the porous cement blocks are used; the average thermal resistance $\mathrm{R}$ of new composite wall itself is $0.345 \mathrm{~m}^{2} \cdot \mathrm{K} / \mathrm{W}$, and the average heat transfer coefficient $\mathrm{K}$ of the wall is $2.024 \mathrm{~W} / \mathrm{m}^{2} \cdot \mathrm{K}$; 
(4) For Type IV, the thermal conductivity coefficient of concrete solid bricks is $1.62 \mathrm{~W} /(\mathrm{m} \cdot \mathrm{K})$, the average thermal resistance $\mathrm{R}$ of the wall is $0.129 \mathrm{~m}^{2} \cdot \mathrm{K} / \mathrm{W}$, and the average heat transfer coefficient $\mathrm{K}$ is $3.588 \mathrm{~W} / \mathrm{m}^{2} \cdot \mathrm{K}$;

(5) The error between the calculated thermal resistance $R$ and the heat transfer coefficient $\mathrm{K}$ of the wall is not more than 5\%, in line with the Energy Efficiency Test Standard for Residential Buildings (JGJ/T132-2009). It can be seen from Figure 10, Figure 11 and Table 5 that among the four types of walls, the Type I has the lowest heat transfer coefficient $\mathrm{K}$ and the best thermal insulation performance; the Type IV has the highest thermal coefficient $\mathrm{K}$ and the worst thermal insulation performance.

There are many factors affecting the thermal performance of the wall, namely, the choice of materials, the way of masonry, and the different constructions, which all affect the thermal performance of the wall to varying degrees. Therefore, in the design, it is necessary to comprehensively consider various factors, and enhance the thermal insulation performance of the wall for improving the living environment, reducing the building energy consumption, and achieving the goal of ecological energy conservation. This is also the significance of this study.

\section{REFERENCES}

[1] Qi, W.Y. (2016). Study of harmonious ecological view of Huizhou ancient dwellings. Journal of Hefei University of Technology (Social Sciences), 30(4): 117121. 3634.2016.04.019

[2] Duan, Z.C., Huang, C.C., Yao, G. (2019). Measurements and radiance simulation analysis of the daylighting performance of Chinese traditional patio houses in Huizhou. Architecture Technique, 2019(01): 119-121.

[3] Huang, Z.J., Yu, M.P., Zheng, L.J., Gong C. (2018). Indoor environment and comfort of Huizhou traditional dwellings. Journal of Civil Architectural \& Environmental Engineering, 40(01): 97-104.

[4] Xu, Y.D., Li, B. (2017). On the evolution and inheritance of Huizhou residential buildings in north Zhejiang Water Towns. Agro Food Industry Hi-Tech, 28(3): 3349-3352.

[5] Zhao, S.D., Guo, H.B., Wang, Y.W. (2015). Ecological environment and traditional craft: Taking Huizhou three carvings as an example. Anthropologist, 21(1-2): 80-88. https://doi.org/10.1080/09720073.2015.11891796

[6] Huang, Z.J., Wu, Z.Q., Yu, M.Q., Dong, Y.M. (2017). The measurement of natural ventilation in Huizhou traditional dwelling in summer. Procedia Engineering, 205:

$1439-1445$ https://doi.org/10.1016/j.proeng.2017.10.350

[7] Huang, Z.J., Liu, J.J., Hao, H.T., Dong, Y.M. (2017). Indoor humidity environment in Huizhou traditional vernacular dwellings of China in summer. Procedia Engineering, 205 ,

$1350-1356$ https://doi.org/10.1016/j.proeng.2017.10.121

[8] Lin, B.R., Gang, T., Wang, P., Song, L., Zhai, G.K. (2004). Study on the thermal performance of the Chinese traditional vernacular dwellings in Summer. Energy and Buildings, 36(1): 73-79. https://doi.org/10.1016/S03787788(03)00090-2

[9] Li, S.L., Li, L., Cao, M.W., Cao, L., Jia, W., Liu, X.P. (2017). Rapid modeling of Chinese Huizhou traditional vernacular houses. IEEE ACCESS, 5: 20668-20683. https://doi.org/10.1109/ACCESS.2017.2754858

[10] Gong, C. (2017). The formation mechanism of the indoor thermal environment and the optimization of building design of Huizhou traditional dwellings in winter. Anhui University of Technology. https://doi.org/CNKI:CDMD:2.1017.273945

[11] Zhang, K. (2016). Research on indoor thermal environment improvements of Huizhou Traditional Residence. Anhui Jianzhu University, 2016

[12] Huang, Z.J., Wang, C.Y., Zhu, L.P. (2017). Thermal Environment Analysis of Huizhou Dwelling in Transitional Season. Building Energy Efficiency, 45(12): 21-23.

[13] Yu, J.H., Ye, H., Xu, X.H., Huang, J.C., Liu, Y.X., Wang, J.B. (2018). Experimental study on the thermal performance of a hollow block ventilation wall. Renewable Energy, 122(7): 619-631. https://doi.org/10.1016/j.renene.2018.01.126

[14] Walker, R., Pavía, S. (2015). Thermal performance of a selection of insulation materials suitable for historic buildings. Building and Environment, 94(P1): 155-165. https://doi.org/10.1016/j.buildenv.2015.07.033

[15] Zhang, Y., Du, K., He, J.P., Yang, L., Li, Y.J., Li, S.H. (2014). Impact factors analysis on the thermal performance of hollow block wall. Energy and Buildings, $75(6)$ : 330-341. https://doi.org/10.1016/j.enbuild.2014.02.037

[16] Hami, K., Draoui, B., Hami, O. (2012). The thermal performances of a solar wall. Energy, 39(1): 11-16. https://doi.org/10.1016/j.energy.2011.10.017.

[17] Fernandes, F.M. (2019). Long-term performance and durability of masonry structures, degradation mechanisms. Health Monitoring and Service Life Design Woodhead Publishing Series in Civil and Structural Engineering 2019, 3-19. https://doi.org/10.1016/B978-008-102110-1.00001-7

[18] Zhou, H.L., Liu, F. (2009). Preliminary study on material, structure and thermal performance of external wall of Huizhou residential buildings. Papers Collection of the 17th Chinese Academic Conference on Residential Buildings, 2009.

[19] Liu, X.T. (2010). Architectural Physics (Version III). Beijing: China Architecture \& Building Press.

[20] Ministry Housing and Urban-Rural Development of the people's Republic of China. Energy Efficiency Test Standard for Residential Buildings (JGJ/T132-2009), Beijing: China Architecture \& Building Press, 2010.

[21] Meng, X., Yan, B., Gao, Y.N., Wang, J., Zhang, W., Long, E.S. (2015). Factors affecting the in situ measurement accuracy of the wall heat transfer coefficient using the heat flow meter method. Energy and Buildings, $\quad 86(01)$ : 754-765. https://doi.org/10.1016/j.enbuild.2014.11.005

[22] Guattari, C., Evangelisti, L., Gori, P., Asdrubali, F. (2017). Influence of internal heat sources on thermal resistance evaluation through the heat flow meter method. Energy and Buildings, 135(01): 187-200. https://doi.org/10.1016/j.enbuild.2016.11.045

[23] Pan, L., Chen, B.L., Fang, Z.H., Zhao, Y.T. (2005). Field measurement and data processing method of envelope's thermal resistance. Building Energy \& Environment, 25(6): 80-84. https://doi.org/10.2139/ssrn.1744744 